\title{
EFEKTIVITAS PERSON-CENTERED ART THERAPY UNTUK MENGURANGI SIMTOM POST-TRAUMATIC STRESS DISORDER (PTSD) PADA PENYINTAS BENCANA GEMPA DI LOMBOK
}

\author{
Issara Rizkya, R. Urip Purwono, Zainal Abidin \\ Fakultas Psikologi Universitas Padjadjaran \\ Jl. Raya Bandung-Sumedang KM. 21 Jatinangor - Sumedang \\ E-mail: issarzky@gmail.com
}

\begin{abstract}
ABSTRAK
Gempa bumi dengan kekuatan 7,0 SR yang terjadi bulan Agustus 2018 lalu di Lombok, Nusa Tenggara Barat merupakan kejadian traumatis bagi para penyintasnya. PTSD (Post-Traumatic Stress Disorder) merupakan gangguan psikologi yang paling sering terjadi. Untuk mengurangi trauma, maka trauma harus diproses melalui pemaknaan sensori. Salah satu intervensi psikoterapi dapat membantu pengekspresian memori sensori adalah psikoterapi seni yang dikenal sebagai Art Therapy. Dalam penerapannya, pendekatan person-centered dapat mendukung individu untuk berkembang dan mencapai potensi penuh dirinya sendiri hingga terjadi proses healing. Tujuan dari penelitian ini adalah mengetahui efektivitas Person-Centered Art Therapy untuk mengurangi simtom PTSD pada penyintas bencana gempa di Lombok. Subjek dalam penelitian ini adalah empat orang wanita di Dusun Semokan, Desa Batu Rakit, Lombok Utara yang dipilih melalui purposive sampling. Metode yang digunakan dalam penelitian ini adalah concurrent embedded approach. Intervensi diberikan secara individual terhadap masing-masing subjek selama lima sesi berdasarkan konsep Creative Connection Process dari Natalie Rogers (1993). Sebelum dan setelah sesi intervensi diberikan, peneliti melakukan pre-dan post-test menggunakan PTSD Symptom Scale yang sudah diuji reliabilitas serta validitasnya oleh Eka Susanty di tahun 2012 dan juga panduan wawancara yang disusun berdasarkan simtomsimtom PTSD. Hasil penelitian menunjukkan bahwa pemberian intervensi Person-Centered Art Therapy dapat menurunkan simtom PTSD pada keempat subjek penelitian. Creative Connection Process yang digunakan dalam penyusunan tema di dalam setiap sesi intervensi, membantu memfasilitasi subjek untuk bisa mengekspresikan diri dengan menyampaikan apa yang dirasakan dan dialami secara terbuka, serta memfasilitasi subjek untuk lebih mengenali dan memahami dirinya sendiri.
\end{abstract}

Kata kunci: person-centered; art therapy; PTSD; bencana alam; gempa bumi

\section{EFFECTIVENESS OF PERSON-CENTERED ART THERAPY TO REDUCE POST-TRAUMATIC STRESS DISORDER (PTSD) SYMPTOM IN SURVIVOR OF LOMBOK EARTHQUAKE}

\begin{abstract}
An earthquake of magnitude 7,0 occurred in August 2018 at Lombok, West Nusa Tenggara is a traumatic event that can cause psychological problems to the survivors. To be able to reduce thetrauma, the trauma must be processed through sensory interpretation. One of the psychotherapy interventions that can help express this sensory memory is an art psychotherapy known as Art Therapy. The purpose of this study is to determine the effectiveness of PersonCentered Art Therapy to reduce the symptoms of PTSD in earthquake survivors in Lombok. The subjects in this study were four women who were survivors of the earthquake disaster in Semokan Hamlet, Batu Rakit Village, North Lombok, who were selected through purposive sampling. The method used in this research is concurrent embedded approach. Interventions were given individually to each subject for five sessions based on the Creative Connection Process by Natalie Rogers. Before and after the intervention session was given, the researchers conducted pre-and post-test using PTSD Symptom Scale which had been tested for reliability and validity by Eka Susanty in 2012 and interview guides compiled based on PTSD symptoms. The results showthat Person-Centered Art Therapy can reduce the symptoms of PTSD in research subjects who are survivors of the earthquake disaster in Lombok. The Creative Connection Process used in the preparation of themes in each intervention session helped facilitate the research
\end{abstract}


subjects to be able to expressed themselves by conveying what was felt and experienced openly and facilitating the subject to better recognized and understood themselves.

Keyword: person-centered; art therapy; PTSD; disaster; earthquake

\section{PENDAHULUAN}

Pada Agustus 2018 telah terjadi gempa bumi dengan kekuatan 7,0 SR di Lombok, Nusa Tenggara Barat. Lombok Utara adalah daerah yang paling terdampak gempa karena merupakan wilayah yang paling dekat dengan pusat gempa (www.bnpb.go.id, 2018). Berdasarkan data yang diperoleh Badan Nasional Penanggulangan Bencana (BNPB), Kerusakan dan kerugian yang diakibatkan oleh gempa ini begitu besar. Menurut BNPB, perlu waktu yang lama untuk dapat memulihkan kehidupan masyarakat dan melakukan pembangunan di wilayah NTB. Pemerintah pusat akan terus mendampingi masyarakat dan Pemerintah Daerah NTB. Proses pendampingan pasca-bencana ini tidak hanya dilakukan dalam bidang rehabilitasi dan rekonstruksi lingkungan fisik, tetapi juga harus dilakukan dalam bidang rehabilitasi psikologis para korban (www.bnpb.go.id, 2018). Korban yang paling terpengaruh oleh bencana adalah mereka yang berada di pusat bencana dan juga di daerah sekitarnya. Berbagai masalah psikologis mungkin akan dialami seseorang setelah mengalami peristiwa traumatis. Reaksi-reaksi yang normal dan wajar yang biasa ditampilkan setelah mengalami peristiwa traumatis meliputi reaksi dari berbagai hal, misalnya fisik, emosional, kognitif, spiritual, dan sosial (Kirschenbaum, 2004).

Meskipun konsekuensi dari bencana dapat menyebabkan berbagai rentang psikopatologi, penelitian yang sudah dilakukan sebelumnya menemukan bahwa PTSD adalah gangguan psikopatologi yang paling sering dipelajari setelah bencana dan juga merupakan psikopatologi utama setelah bencana. PTSD atau Post-Traumatic Stress Disorder merupakan gangguan psikologis yang sering muncul pada korban bencana, baik bencana alam maupun bencana buatan manusia (Neria, Nandi, \& Galea, 2008). Trauma yang dialami disebabkan oleh pengalaman langsung atau menyaksikan atau mempelajari mengenai kejadian traumatis yang mengakibatkan kematian, luka parah, atau ancaman terhadap kesejahteraan psikologis pada seseorang atau orang lain. Sebagian kejadian traumatis muncul hanya sekali saat yang lain bisa mengalami beberapa kali (Fullerton \& Ursano, 2005).

Berdasarkan DSM-V, seseorang bisa mendapatkan diagnosis PTSD salah satunya jika mengalami atau menyaksikan kejadian traumatis secara langsung. Mereka mungkin mengalami ingatan berulang serta mimpi buruk yang berkaitan dengan kejadian traumatis (re-experiencing). Terdapat pula usaha menghindar terhadap hal-hal yang mengingatkan terhadap kejadian traumatis (avoidance). Mereka juga mungkin merasakan kepercayaan serta emosi negatif sehari-hari (negative alterations in cognitions and mood). Perubahan juga akan dialami seperti menjadi lebih mudah tersinggung atau marah, lebih waspada, mudah kaget, mengalami kesulitan konsentrasi, dan gangguan tidur (alterations in arousal and reactivity). Pada individu yang mengalami PTSD, mereka akan menghindari stimulus yang membuat mereka terancam (Stein, Friedman, \& Blanco, 2011). Tingkat keparahan dari PTSD dapat menyebabkan stres yang signifikan secara klinis atau gangguan dalam fungsi sehari-hari (North, Oliver, \& Pandya, 2012) .

Pada seseorang yang mengalami kejadian traumatis, pengalaman tersebut pertama kali diterima melalui sensori. Pengalaman tersebut diubah oleh sistem limbik menjadi sebuah kode yang disimpan dalam memori sebagai bentuk dari realitas sensori. Pada seseorang yang mengalami trauma, untuk dapat menguranginya maka trauma tersebut harus diproses melalui pemaknaan sensori. Ekspresi dari memori sensori mengenai kejadian traumatis sangat menentukan keberhasilan intervensi (Everly \& Lating, 2002).

Salah satu media yang dapat membantu pengekspresian memori sensori adalah seni. Seni merupakan cara yang alami bagi ekspresi sensori karena melibatkan sentuhan, bau, dan indera lainnya selama pembuatan karya seni dilakukan. Kapasitas dari pembuatan karya seni atau art making telah terbukti efektif dalam "menyentuh" memori sensori di sistem limbik, sehingga membuatnya menjadi salah satu alat yang potensial dalam intervensi trauma (Pamelia, 2015). Pada seseorang yang mengalami trauma, mereka akan memiliki gambaran visual yang kuat mengenai kejadian traumatis yang mereka alami. Art making akan membantu individu mengomunikasikan rasa takut, marah, atau kehilangan yang mereka alami (Malchiodi, 2007). Intervensi psikoterapi seni dikenal dengan istilah Art Therapy yang merupakan bentuk terapi dinamis dan melibatkan individu untuk berpartisipasi dalam proses treatment itu sendiri.

Art Therapy merupakan hasil perpaduan dari seni dan psikologi. Pada Art Therapy, media seni, proses kreatif, dan hasil karya seni dimanfaatkan untuk mengungkapkan perasaan, berdamai dengan konflik emosional, meningkatkan kesadaran diri, menurunkan kecemasan, serta meningkatkan keberhargaan diri (Malchiodi, 2007). Melalui Art Therapy, individu dapat mengekspresikan emosi yang dialaminya dengan cara yang aman hingga ia mampu menghadapi dan menerima hal tersebut (Malchiodi, 2007). 
Pada seseorang yang mengalami PTSD, Art Therapy membantunya untuk menyampaikan pikiran, perasaan, serta ide yang ia miliki mengenai gambar kejadian traumatis dalam bentuk yang lebih jelas dan nyata. Melalui karya seni tersebut, mereka dapat diajak untuk berkomunikasi mengenai apa yang terjadi pada dirinya dan membantu untuk lebih memahami kondisi dirinya sendiri (Rubin, 2005). Di dalam Art Therapy, terdapat berbagai macam teknik yang dapat dilakukan untuk membuat karya seni, di antaranya adalah menggambar, melukis, modeling, konstruksi dua atau tiga dimensi, menari, musik, membuat puisi, drama, dan membuat pertunjukan boneka.

Penelitian mengenai penanganan trauma telah membuktikan bahwa salah satu cara yang bisa dilakukan adalah dengan mengubah pengalaman traumatis di dalam pikiran ke dalam bentuk gambar (Rubin, 2010). Menggambar membantu klien menuangkan konsep dalam dirinya dalam bentuk yang nyata di hadapan mereka. Tugas menggambar yang spesifik telah terbukti efektif dalam "menyentuh" memori sensori pada individu yang mengalami trauma untuk bisa mengurangi dampak jangka panjang dari PTSD (Everly \& Lating, 2002). Penelitian lain pada pejuang veteran menunjukkan bahwa Art Therapy mampu menurunkan PTSD yang dialami pada pejuang veteran perang (Esparza, 2015).

Memori traumatis ketika diekspresikan dalam bentuk gambar secara tidak sadar dapat mengurangi ancaman di dalam diri individu (Malchiodi, 2007). Menggambar memberikan kesempatan kepada individu untuk dapat mengomunikasikan pikiran, perasaan, perhatian, harapan, serta keinginannya dengan cara yang aman. Proses psikoterapeutik ini akan semakin efektif jika individu merasa diterima dan dipahami oleh fasilitator atau terapis. Dengan adanya perasaan tersebut, maka terjadilah proses healing (Rogers, 1993). Saat fasilitator atau terapis mampu mendengarkan secara mendalam emosi dari klien dan juga menghargai kemampuan klien untuk dapat menemukan jawabannya sendiri, hal tersebut memberi mereka sesuatu yang sangat berarti. Sikap empati dan penerimaan yang ditunjukkan fasilitator atau terapis dapat memberikan kesempatan kepada individu untuk dapat mengembangkan diri dan mencari potensi unik di dalam dirinya. Penerimaan dan pemahaman inilah yang akan membuat klien merasa aman dan dapat mengekspresikan dirinya.

Carl Rogers mengenalkan pendekatan clientcentered atau person-centered therapy yang menekankan peran dari terapis untuk dapat bersikap empati, terbuka, menjadi diri sendiri, serta peduli terhadap klien secara mendalam. Dasar dari pendekatan ini adalah keyakinan bahwa setiap individu memiliki kapasitas untuk bisa mengarahkan dirinya sendiri (Feist \& Feist, 2009).

Pada individu yang mengalami trauma, berbagai intervensi penanganan trauma yang biasa diberikan adalah CBT (Cognitive Behavioral Therapy), EFT
(Emocional Focus Therapy), dan EMDR (Eye Movement Desensitization and Reprocessing) Therapy (Friedman, Keane, \& Resick, 2014). Psikoterapi ini berfungsi untuk menormalisasi perilaku baik melalui pikiran dan juga membantu para individu yang mengalami trauma melepaskan emosi yang dirasakan (Wilson, Friedman, \& Lindy, 2001). Dengan menggunakan Person-Centered Art Therapy yang diintegrasikan dengan pendekatan person-centered dalam Art Therapy, individu tidak hanya dibawa untuk dapat berpikir dan melepaskan emosi yang dirasakan, tetapi juga individu diajak untuk mengeksplorasi dirinya dan menemukan makna dari pengalamannya (Rogers, 1993).

Dalam penerapan Art Therapy, pendekatan personcentered dalam proses diskusi dari karya yang dibuat dapat mengarahkan individu untuk berkembang dan mencapai potensi penuh dirinya sendiri. Pertumbuhan individu ini dapat dicapai melalui self-awareness, selfunderstanding, dan insight yang diperoleh melalui proses penggalian emosi (Rogers, 1993). Perasaan dan emosi individu adalah sumber energi yang jika terhubung dengan seni akan mudah untuk dikeluarkan dan diubah. Natalie Rogers mengenalkan sebuah konsep, yaitu Creative Connection Process yang menjelaskan proses bagaimana individu dapat mencapai tingkat kreatif di dalam dirinya yaitu dengan beberapa tahap di antaranya expressing the self, selfunderstanding, empowering self, experimentation and risking, dan have a faith (Rogers, 1993). Proses ini yang kemudian akan membantu individu menemukan makna dari pengalaman yang dihadapinya (Rogers, 1993). Oleh karena itu, peneliti tertarik untuk meneliti apakah Person-Centered Art Therapy efektif dalam mengurangi simtom PTSD (Post-Traumatic Stress Disorder) pada penyintas bencana gempa di Lombok.

\section{METODE}

Rancangan penelitian yang digunakan dalam penelitian ini adalah concurrent embedded approach yaitu strategi penelitian mixed methods di mana data kuantitatif dan kualitatif dikumpulkan secara bersamaan. Pendekatan dalam penelitian ini memiliki metode utama yang menjadi panduan dalam proses penelitian, yaitu data kualitatif dan data sekunder yang menjadi pendukung dalam prosedur penelitian yaitu data kuantitatif (Creswell, 2009). Data kuantitatif akan diperolah melalui kuesioner pre- dan post-test untuk mengukur tingkat indikasi simtom PTSD, sedangkan data kualitatif diperoleh melalui berbagai macam sumber, yaitu wawancara, observasi, lembar penilaian, dan pencatatan proses intervensi yang diberikan. Pendekatan ini dilakukan untuk memperoleh gambaran serta hasil yang lebih mendalam dan komprehensif dari setiap sampel.

Teknik pengambilan sampel yang digunakan berdasarkan pada pendekatan non-probability, yaitu purposive sampling dengan memilih subjek yang 
sesuai dengan karakteristik yang ditetapkan yaitu wanita, usia 20 - 30 tahun, dan memiliki keluhan reaksi-reaksi trauma setelah gempa. Dalam penelitian ini terdapat empat orang subjek yang merupakan wanita dengan rentang usia 22 - 29 tahun yang merasakan dampak langsung gempa, baik secara fisik maupun psikis. Lokasi penelitian dilakukan di Dusun Semokan, Desa Sukadana, Kec. Bayan, Kab. Lombok Utara, NTB.

Intervensi yang dilakukan adalah Person-Centered Art Therapy. Selama proses penelitian ini berlangsung, peneliti mendapatkan supervisi dari Art Therapist yaitu Ardhana Riswarie, MA, AThR. Sebelum peneliti melakukan penyusunan modul intervensi, peneliti telah mengikuti Program Training to Trainer (TTT) Art Therapy bersama dua orang Art Therapist yaitu Emmanuela Ariana Halim, AThR (Indonesia) dan Myoung Ju Jung, AThR (Korea) dalam setting kebencanaan di Lombok pada Februari 2019. Modul yang kemudian disusun juga telah melalui proses expert review oleh Ardhana Riswarie, MA, AThR dan Aulia Iskandarsyah, M.Psi., M.Sc., PhD., Psikolog.

Intervensi yang dilakukan terdiri dari 5 sesi. Sebelum intervensi diberikan, subjek diwawancara untuk mengetahui simtom PTSD yang dirasakan sebagai dampak dari bencana gempa yang dialami dan juga diberikan kuesioner PTSD Symptom Scale untuk mengetahui tingkat indikasi PTSD yang dimiliki.. Kemudian intervensi diberikan selama lima sesi yang diturunkan berdasarkan Teori Creative Connection Process dari Natalie Rogers (1993) dengan tema-tema gambar yang berbeda di setiap pertemuan. Di dalam setiap pertemuan, subjek akan diminta menggambar sesuai dengan tema dan arahan peneliti, kemudian subjek akan mendiskusikan karya dan pengalamannya bersama terapis. Dalam proses ini, terapis menggunakan pendekatan person-centered kepada subjek yang mana proses diskusi lebih banyak direfleksikan kepada subjek agar subjek dapat mengeksplorasi dan mengenali dirinya lebih mendalam. Setelah terapi selesai diberikan selama lima pertemuan, subjek diwawancara dan diberikan kuesioner PTSD Symptom Scale kembali untuk mengetahui perubahan yang dirasakan dari simtomsimtom PTSD setelah intervensi diberikan. Kuesioner yang digunakan merupakan kuesioner yang sudah dinyatakan reliabel dan valid berdasarkan penelitian Eka Susanty (2012) yang merupakan adaptasi dari PTSD Symptom Scale dari Foa, Riggs, Dancu, \& Rothbaum (1993).

Untuk mendukung penelitian ini, peneliti juga menyiapkan lembar evaluasi partisipan yang dirancang oleh peneliti dan diberikan pada setiap sesi terapi. Di dalam lembar evaluasi partisipan selalu terdapat itemitem yang sama yang mengukur penilaian partisipan terhadap diri mereka setelah mengikuti sesi menggambar dan diskusi bersama terapis. Selain itu, untuk mendukung pendekatan person-centered yang dilakukan, maka peneliti juga meminta para subjek

mengisi lembar penilaian fasilitator yang berisi butirbutir pernyataan mengenai sikap fasilitator terhadap subjek yang diturunkan sesuai dengan prinsip-prinsip person-centered. Seluruh lembar evaluasi ini juga telah melalui review terlebih dahulu bersama dengan modul yang disusun.

Setiap sesi berlangsung selama kurang lebih $60-90$ menit. Untuk mengawali sesi, peneliti selalu memulainya dengan kegiatan warm-ups, yaitu kegiatan menggambar yang bertujuan untuk membantu subjek untuk lebih mengenal dan terbiasa dengan media menggambar yang disediakan sehingga diharapkan ketika masuk ke sesi kegiatan inti terapi, para subjek sudah lebih percaya diri dalam menggunakan media dan material yang disediakan.

Setiap sesi memiliki tujuannya sendiri yang kemudian setiap aktivitas di dalam setiap sesi akan disesuaikan dengan tujuan tersebut. Tema-tema berbeda diberikan kepada subjek sebagai arahan dalam membuat karya masing-masing. Tabel 1 menjelaskan gambaran tema dan tujuan dari setiap sesi yang dilakukan di dalam kegiatan intervensi ini.

\section{Tabel 1. Gambaran Umum Intervensi}

\begin{tabular}{|c|c|}
\hline Sesi & Tema \& De \\
\hline Sesi 1 & Lost and Found: \\
\hline Expressing 1 & \\
\hline Self & Subjek \\
\hline Tujuan: & diminta memejamkan mata \\
\hline Mengek & dan membayangkan kondisi \\
\hline pengalaman yang & kehidupannya di 1 tahun \\
\hline dirasakan & sebelumnya \\
\hline perisitiwa gempa & terjadi. Kemudian \\
\hline bagaimana & diminta \\
\hline & membayangkan \\
\hline terl & kehidupannya sata in \\
\hline
\end{tabular}

Menggambar: Subjek diminta menggambarkan hal-hal yang hilang dan hal-hal yang baru didapatkan setelah gempa terjadi dan diminta untuk menceritakan bagaimana perasaan yang dirasakan.

\section{Sesi 2 \\ Self- \\ Understanding}

Tujuan:

Memahami

perasaan dan

karakteristik diri.

\section{Colors and Personality:}

Guided imagery: Subjek diminta untuk menutup mata dan merasakan setiap bagian dari tubuhnya dimulai dari ujung kaki sampai dengan ujung kepala. Subjek juga diminta untuk menggerakkan bagian-bagian tubuh tersebut dan merasakan apa yang dirasakan oleh tubuhnya. Setelah itu subjek diminta membuka mata dan 


\begin{tabular}{|c|c|}
\hline & $\begin{array}{l}\text { merefleksikan perasaan yang } \\
\text { dirasakan pada fisiknya. } \\
\text { Menggambar: Subjek diminta } \\
\text { untuk merasakan perasaan } \\
\text { yang dirasakan di dalam } \\
\text { dirinya. Kemudian diminta } \\
\text { untuk menentukan perasaan } \\
\text { yang dirasakannya dengan } \\
\text { memilih warna yang } \\
\text { 'mewakili' perasaan tersebut, } \\
\text { kemudian menggambarkan } \\
\text { satu hal yang menggambarkan } \\
\text { dirinya dengan warna } \\
\text { tersebut. }\end{array}$ \\
\hline $\begin{array}{l}\text { Sesi } 3 \\
\text { Empowering } \\
\text { Self } \\
\text { Tujuan: } \\
\text { Menyadari } \\
\text { sumber daya } \\
\text { serta kekuatan } \\
\text { yang dimiliki } \\
\text { oleh diri. }\end{array}$ & $\begin{array}{l}\text { Survivor: } \\
\text { Menggambar: Subjek diminta } \\
\text { menggambarkan dirinya } \\
\text { sebagai seorang pahlawan dan } \\
\text { menuliskan tiga hal yang } \\
\text { menjadi kekuatan dirinya } \\
\text { berjuang hidup hingga saat } \\
\text { ini. }\end{array}$ \\
\hline $\begin{array}{l}\text { Sesi } 4 \\
\text { Experimentation } \\
\text { and Risking } \\
\text { Tujuan: } \\
\text { Menentukan } \\
\text { tujuan yang ingin } \\
\text { dicapai dan juga } \\
\text { menghayati } \\
\text { bagaimana diri } \\
\text { mereka berproses } \\
\text { menuju tujuan } \\
\text { tersebut. }\end{array}$ & 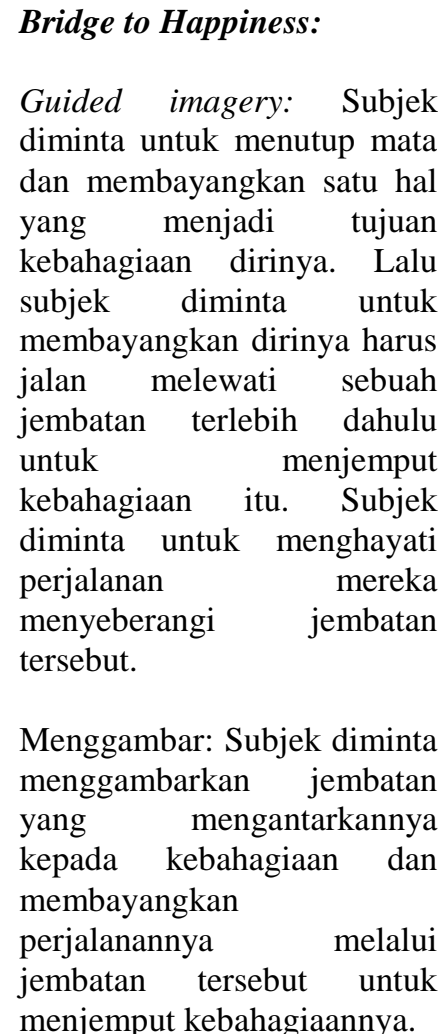 \\
\hline $\begin{array}{l}\text { Sesi } 5 \\
\text { Have Faith } \\
\text { Tujuan: } \\
\text { Memiliki } \\
\text { harapan serta } \\
\text { keyakinan yang } \\
\text { ingin dicapai } \\
\text { untuk dirinya, } \\
\text { keluarga, dan }\end{array}$ & $\begin{array}{l}\text { Menggambar: Subjek diminta } \\
\text { menggambarkan sebuah } \\
\text { pohon harapan yang berisi } \\
\text { harapannya untuk dirinya, } \\
\text { keluarga, dan satu orang yang } \\
\text { berarti bagi mereka. }\end{array}$ \\
\hline
\end{tabular}

orang-orang di
sekitar.

Data kualitatif yang diperoleh diolah menggunakan content analysis dengan menganalisis hasil dari diskusi yang dilakukan setelah menggambar antara subjek dengan terapis. Diskusi dilakukan untuk melihat proses psikologis yang terjadi pada setiap subjek dan perubahan yang dirasakan subjek simtom PTSD yang dirasakan sebelum dan sesudah intervensi diberikan, sedangkan data kuantitatif dibandingkan untuk melihat perubahan skor saat pre-dan post-test.

\section{HASIL DAN PEMBAHASAN}

Berdasarkan data yang diperoleh, Tabel 2 menjelaskan hasil dari intervensi Person-Centered Art Therapy yang diberikan dalam penurunan simtom PTSD keempat subjek penelitian.

Tabel 2. Perubahan Skor Pre-test dan Post-test Tingkat PTSD Masing-Masing Subjek

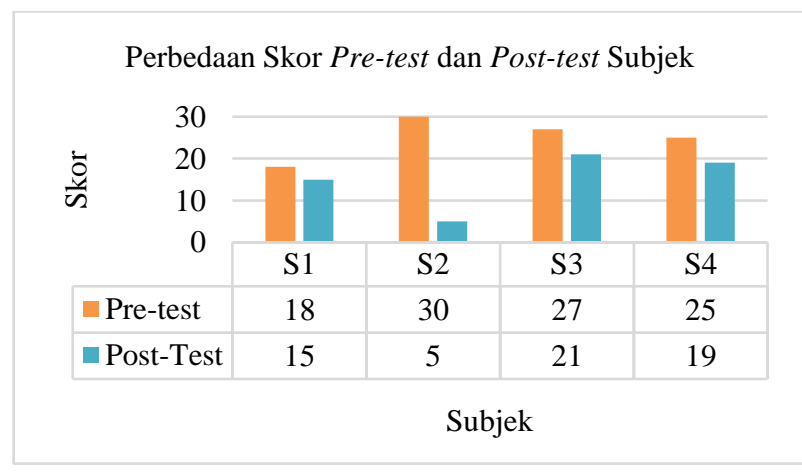

Berdasarkan analisis kuantitatif deskriptif, terjadi penurunan skor PTSD berdasarkan skala PTSD Symptom Scale pada ibu-ibu di Dusun Semokan yang menjadi subjek penelitian. Penurunan skor simtom PTSD ini juga sejalan dengan data kualitatif dari keempat subjek mengenai perubahaan yang dirasakan setelah mengikuti intervensi. Intervensi ini menjadi wadah untuk menyalurkan hal-hal yang dipikirkan dan dirasakan oleh keempat subjek setelah mengalami kejadian gempa. Dengan keberhasilan keempat subjek dalam menyampaikan pikiran dan perasaan mereka melalui gambar dan kemudian menceritakannya dalam sesi diskusi, hal ini menumbuhkan perasaan positif pada subjek. Perasaan-perasaan ini adalah perasaan bahagia, lega, dan nyaman. Keempat subjek merasa melalui intervensi yang diberikan, mereka dapat menyampaikan berbagai macam pikiran, kekhawatiran, dan ketakutan mereka yang sebelumnya tidak dapat mereka sampaikan.

Jika melihat kepada prinsip-prinsip PersonCentered Art Therapy, proses pengekspresian emosi ini merupakan proses yang perlu dilalui seorang individu untuk mencapai self-awareness, self-understanding, 
dan juga memunculkan insight yang kemudian menjadi pertumbuhan pribadi dari individu tersebut (Rogers, 1993). Perubahan simtom PTSD yang terjadi pada keempat subjek ini dijelaskan melalui kerangka Creative Connection Process yang sudah dilalui keempat subjek dari sesi-sesi di dalam PersonCentered Art Therapy yang diberikan. Seluruh sesi yang diberikan membantu subjek untuk memproses ingatan, pikiran, dan perasaan akan kejadian traumatis yang ada di dalam diri subjek, sehingga dapat terhubung dengan kondisi realita yang membuat subjek lebih menyadari dan memahami apa yang terjadi kepada diri mereka.

Pada sesi pertama, yaitu tahap Expressing The Self, subjek diajak untuk dapat membayangkan kembali kejadian traumatis yang dialami, mengidentifikasi halhal yang berubah dalam hidupnya ke dalam bentuk gambar, dan menyadari apa yang dirasakan dari perubahan yang dialaminya. Sesi ini membantu subjek untuk memproses ekspresi dirinya melalui gambar yang dibuatnya (Rogers, 1993). Ingatan serta pikiran mengenai kejadian traumatis dihadirkan kembali dengan cara yang aman sehingga subjek mampu menghayati hal yang ada di dalam dirinya, mengeksplorasi pengalaman yang dilalui, hingga akhirnya menyampaikannya. Proses ini membuat subjek dapat lebih memahami dan menerima pengalaman kejadian traumatis yang sebelumnya dihindari.

Di sesi kedua, yaitu tahap Self-Understanding, subjek mengidentifikasi perasaan yang mendominasi dirinya dalam beberapa waktu terakhir dengan menuangkannya dalam bentuk warna. Warna tersebut yang kemudian dikembangkan oleh subjek menjadi sebuah gambar yang mendeskripsikan dirinya. Hal ini membantu subjek memproses pengalaman emosi yang dirasakannya yang mungkin secara tidak sadar dialami, sehingga membantu subjek untuk lebih dapat memahami dunia dalam dirinya. Proses ini juga memberikan ruang bagi subjek untuk dapat mengidentifikasi dengan jelas emosi yang dirasakan dan dihindari sebelumnya, sehingga subjek dapat memahami dirinya sendiri.

Pada seseorang yang mengalami kejadian traumatis, pembuatan karya seni dapat membantu mengekspresikan trauma dan mengomunikasikan rasa takut, marah, dan kehilangan yang berhubungan dengan kejadian. Ketika individu membuat sebuah gambar, ia menyampaikan perasaan, pikiran, ide, dan membuatnya menjadi jelas dan nyata. Gambar yang terdapat di atas kertas lebih memungkinkan subjek untuk merespons, menjelaskan gambar, dan menceritakannya. Simtom-simtom PTSD yang dirasakan yaitu re-experiencing dan avoidance yang merupakan ingatan mengganggu dengan durasi memori sensori singkat, memiliki kualitas here-andnow, dan tidak memiliki konteks, diekspresikan ke dalam bentuk karya seni yang kemudian secara visual menjadi lebih jelas dan nyata. Hal ini yang kemudian membantu subjek untuk lebih mampu menghadapi dan menerima kejadian traumatis tersebut.

Tahap berikutnya di sesi ketiga, yaitu Empowering Self, subjek diminta untuk menggambarkan dirinya dan menuliskan hal-hal positif yang menjadi kekuatan dalam dirinya dalam menghadapi kejadian-kejadian yang dilaluinya, terutama satu tahun terakhir setelah melalui kejadian traumatis. Proses identifikasi kekuatan diri ini membantu subjek untuk fokus terhadap aspek-aspek positif di dalam dirinya, sehingga subjek mampu merasakan emosi yang positif dan juga menumbuhkan kepercayaan yang juga positif terhadap dirinya sendiri. Energi negatif yang sebelumnya dirasakan diubah menjadi energi yang positif pada diri subjek. Perubahan energi ini yang juga membantu subjek menangani simtom PTSD, yakni negative alterations in cognitions and mood. Kepercayaan negatif, keaadan emosi negatif terus menerus, serta ketidakmampuan merasakan emosi positif diubah melalui proses intervensi, sehingga memunculkan insight positif dengan mengenali potensi diri.

Pada sesi keempat, yaitu tahap Experimentation and Risking, subjek mencoba untuk mengidentifikasi tujuan kebahagiaan yang ingin dicapai dan mencoba untuk bergerak secara imagery dalam mencapai tujuan tersebut. Dalam proses ini, subjek menghayati dan mengidentifikasi kendala-kendala serta ancaman yang mungkin muncul. Situasi tersebut dibayangkan oleh subjek agar subjek dapat mengantisipasi hal tersebut melalui potensi yang dimiliki dan juga perencanaan lain yang dapat dipersiapkan lebih dulu. Tujuan ini yang kemudian membuat subjek menjadi lebih fokus dan dapat mengatasi berbagai kekhawatiran dan kewaspadaan yang dirasakan sebelumnya. Hal ini berkaitan pula dengan simtom alterations in arousal and reactivity yang mana subjek mengalami perubahan dorongan dan reaktivitas yang tidak terkontrol.

Pada sesi yang terakhir, yaitu tahap Have Faith, subjek menggambarkan dan membentuk pohon berisi harapan-harapan yang dimilikinya terhadap dirinya sendiri dan juga keluarganya. Harapan-harapan ini merupakan bentuk penguatan akan kepercayaan positif subjek terhadap kemampuan dirinya sendiri dalam mencapai tujuan yang diinginkannya. Harapan dan keyakinan ini diproses, sehingga menjadi sebuah pemaknaan yang positif bagi subjek yang mendukung terciptanya diri subjek yang bertumbuh dan berkembang menjadi kesatuan yang lebih terintegrasi antara dunia di dalam dan di luar dirinya. Proses-proses yang dilalui subjek ini mendukung penurunan serta pengurangan simtom-simtom yang dirasakan oleh keempat subjek.

Tabel 3. Perubahan Simtom PTSD Subjek 1

\begin{tabular}{|c|c|c|c|}
\hline Pre-test & & Post-test & \\
\hline Skor total: 18 & & Skor total: 15 & \\
\hline 1. Re-experiencing & & 1. Re-experiencing & \\
\hline (skor & S1 & (skor & $\mathrm{S} 1$ \\
\hline
\end{tabular}




\begin{tabular}{|c|c|c|c|}
\hline 4. & 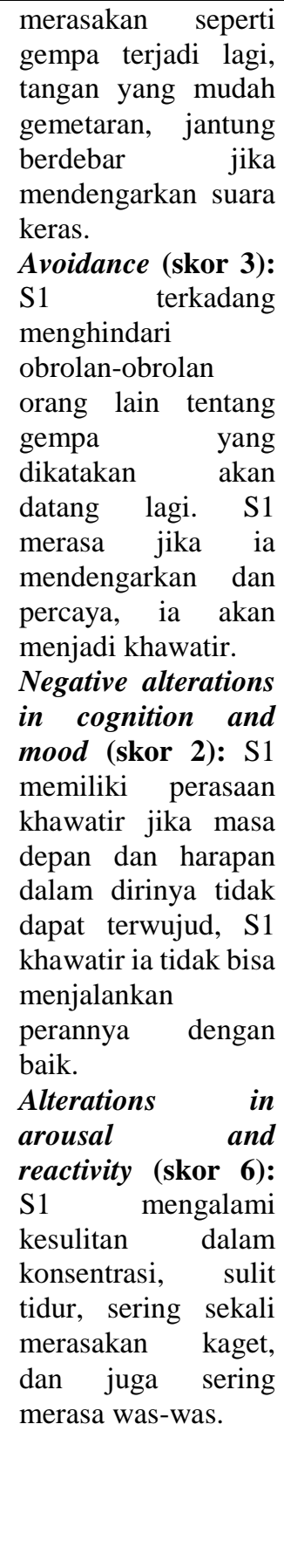 & 3. & 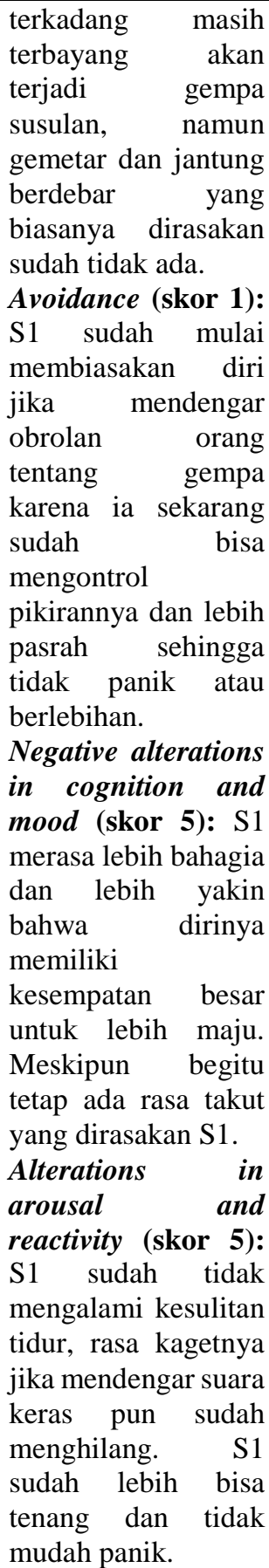 \\
\hline
\end{tabular}

Pada S1 (Subjek 1), ia menjalankan setiap tugas menggambar yang diberikan dengan terlihat sungguhsungguh. Pada setiap sesi diskusi, S1 menyampaikan berbagai hal yang ada di pikiran dan perasaannya dengan terbuka. S1 menyampaikan pengalaman yang dirasakannya setelah gempa terjadi, bagaimana peran baru yang diperolehnya saat ini setelah gempa terjadi, berbagai kekhawatiran yang dimiliki S1 dalam menjalankan peran dan mengejar keinginannya yang juga sama besarnya dengan motivasi di dalam dirinya untuk berkembang dan lebih maju dari kondisinya saat ini. Proses creative connection yang berlangsung di dalam sesi intervensi membawa S1 kepada keyakinan yang lebih besar terhadap dirinya bahwa ia mampu mewujudkan harapan-harapan untuk dirinya, untuk anaknya, dan untuk keluarganya. Pada proses yang dilalui oleh S1, karya yang dihasilkan berfungsi sangat baik dalam membantu S1 mengomunikasikan apa yang terdapat di dalam pikiran dan perasaannya. S1 memiliki banyak potensi di dalam diri dan keinginan yang besar untuk bergerak maju. Kesempatan S1 dalam mengeksplorasi diri dan menggali diri dalam proses Person-Centered Art Therapy ini membantu S1 menemukan energi positif yang terdapat di dalam dirinya. Di samping itu, masih terdapat kekhawatiran pada diri S1 mengenai masa depan yang akan dihadapinya.

\section{Tabel 4. Perubahan Simtom PTSD Subjek 2}

\begin{tabular}{|c|c|}
\hline Pre-test & Post-test \\
\hline Skor total: 30 & Skor total: 5 \\
\hline 1. Re-experiencing & eriencing \\
\hline (skor 10): & cose \\
\hline memiliki bayangan & mengenai \\
\hline bahwa gempa terjadi & terjadi lagi sudah \\
\hline lagi, S2 juga sering & berkurang. Mimpi \\
\hline terbayang mengenai & buruk, \\
\hline $\begin{array}{l}\text { kejadian gempa, } \\
\text { seperti suara orang }\end{array}$ & $\begin{array}{l}\text { gemetar, dan suara- } \\
\text { suara }\end{array}$ \\
\hline menangis, mimpi & mengganggu \\
\hline buruk & sebelumnya sudah \\
\hline $\begin{array}{l}\text { tsunami, perasaan } \\
\text { sedih dan mudah }\end{array}$ & $\begin{array}{l}\text { tidak dirasakan S2. } \\
\text { Avoidance (skor 2): }\end{array}$ \\
\hline gemetaran. & S2 sudah mulai tidak \\
\hline 2. Avoidance (skor 4): & terlalu menghindari \\
\hline menghindari & rumah \\
\hline untuk masuk ke & tinggali, namun \\
\hline dalam rumah karena & karena masih ada \\
\hline membuatnya takut & waspada jadi S2 \\
\hline kejadian & membiasakan \\
\hline $\begin{array}{l}\text { gempa, S2 juga } \\
\text { menghindari } \text { untuk }\end{array}$ & $\begin{array}{l}\text { lama-lama } \\
\text { rumah/tokonya. }\end{array}$ \\
\hline
\end{tabular}
banyak beraktivitas dengan orang-orang.

3. Negative alterations in cognition and mood (skor 4): S2 menyatakan bahwa ia tidak ingat kejadian gempa terjadi, namun ia hanya mengingat suara orang menangis.

4. Alterations

arousal in reactivity (skor 12): S2 mengalami sulit tidur, sulit tidur terutama saat gempa terjadi lagi di pagi
3. Negative alterations in cognition and mood (skor 0): S2 mengatakan sesekali ia masih teringat dengan kejadian gempa yang datang, namun sudah terbiasa dengan suara-suara. Masih ada perasaan takut yang dirasakan.

4. Alterations in
arousal and
reactivity (skor 2):
$\mathrm{S} 2$ sudah tidak
mengalami kesulitan
tidur, masih ada
sedikit perasaan was-




\begin{tabular}{lrlr}
\hline atau siang hari, & & was ketika sedang di \\
merasa tidak tenang, & dalam rumah atau \\
selalu was-was & toko, dan sudah tidak \\
menghadapi hari & was-was & \\
Minggu. & & menghadapi & hari \\
& & Minggu & karena \\
& & berpikiran gempa \\
& akan datang. & \\
\hline
\end{tabular}

Pada S2 (Subjek 2), ia dapat mengikuti setiap tugas menggambar yang diberikan dengan baik. Hanya saja ketika proses diskusi dari apa yang digambar, peneliti membutuhkan usaha lebih untuk dapat membuat S2 menyampaikan apa yang dirasakan dan dipikirkan olehnya. Pada dua sesi awal, S2 terlihat kurang fokus dan sering menanyakan kembali mengenai pertanyaan yang disampaikan peneliti. Namun, pada sesi ketiga hingga akhir, S2 menjadi lebih fokus, meskipun saat bercerita $\mathrm{S} 2$ menyampaikannya dengan cukup ringkas.

Pada proses creative connection yang dilakukan selama intervensi, S2 menyampaikan kekhawatiran dirinya mengenai kondisinya yang sedang hamil. Pengalaman dan bayangan mengenai gempa menjadi sumber kekhawatiran S2 jika nanti dirinya menjalani proses persalinan. Kekhawatiran ini yang kemudian menjadi pintu peneliti untuk mengajak S2 mengeksplorasi sumber daya yang dimiliki dalam mengantisipasi perasaan khawatirnya. Di samping itu, kehamilan yang sedang dilalui S2 merupakan sumber energi dan kebahagiaan yang dimilikinya, sehingga penantian S2 menyambut sang buah hati menjadi hal yang dituju dan menjadi harapan untuk kehidupan yang lebih positif. Perasaan dan pemaknaan ini yang dipertahankan dan dijaga selama intervensi berlangsung. Pada proses yang dilalui oleh S2, karya yang dihasilkan berfungsi cukup baik dalam membantu peneliti untuk dapat lebih memahami apa yang dirasakan oleh S2 dengan menanyakan hal-hal yang terdapat di dalam gambar tersebut, sehingga S2 dapat mengomunikasikan apa yang terdapat di dalam pikiran dan perasaannya.

\section{Tabel 5. Perubahan Simtom PTSD Subjek 3}

\begin{tabular}{|c|c|}
\hline Pre-test & Post-test \\
\hline Skor total: 27 & Skor total: 21 \\
\hline 1. Re-experiencing & 1. Re-experiencing \\
\hline (skor 7): S3 sering & (skor 8): \\
\hline merasakan seolah & terkadang \\
\hline gempa terjadi lagi & mengalami mimpi \\
\hline terutama setelah & buruk jika ada isu- \\
\hline terjadi gempa di pagi & isu dari orang lain \\
\hline atau siang harinya, & gempa. \\
\hline ada perasaan sedih, & Perasaan \\
\hline mudah gemetaran, & gempa terjadi lagi, \\
\hline sakit kepala, dan & gemetaran, \\
\hline jantung berdebar & kepala, dan jantung \\
\hline jika mendengar & berdebar sudah \\
\hline suara keras. & hilang. \\
\hline
\end{tabular}

2. Avoidance (skor 1): Pada simtom ini, S3 tidak menyampaikan bahwa ada yang ia rasakan.

3. Negative alterations in cognition and mood (skor 9): S3 merasakan

kekhawatiran bahwa apa yang ia harapkan di masa depan tidak bisa tercapai, lalu ada perasaan bahwa dirinya tidak ingin berbaur dengan yang lain.

\section{Alterations}

arousal in reactivity (skor 10): S3 memiliki kesulitan tidur terutama jika di hari tersebut ada gempa terjadi, selalu dalam kondisi was-was dan khawatir kepada kondisi anak yang bermain di luar rumah.

Pada S3 (Subjek 3), ia menjalankan setiap tugas menggambar yang diberikan dengan sangat sungguhsungguh. Pada sesi pertama, S3 menyampaikan pengalaman hidupnya yang berat dan dilalui bersama dengan kakeknya, namun ia kehilangan kakeknya setelah gempa terjadi. Hal ini menjadi sebuah kesedihan mendalam pada diri S3 yang tidak pernah diungkapkan kepada siapa pun. Melalui sesi intervensi ini, S3 dapat mengeluarkan emosi-emosi negatif yang dirasakannya dan mengubahnya menjadi energi positif yang membuatnya menjadi lebih semangat menjalani kehidupan sehari-hari. Proses creative connection mampu membawa S3 untuk mengeksplorasi dirinya dan menemukan emosi positif dan sumber kebahagiaan di dalam dirinya sendiri. Pada proses yang dilalui oleh S3, karya yang dihasilkan berfungsi sangat baik dalam membantu S3 mengomunikasikan apa yang terdapat di dalam pikiran dan perasaannya. S3 dapat melepaskan seluruh emosi negatif yang selama ini menahan dirinya untuk bisa menampilkan diri dengan optimal. Proses ini yang membawa perubahan pada simtom-simtom PTSD yang dialami S3.

\section{Tabel 6. Perubahan Simtom PTSD Subjek 4}

\begin{tabular}{cc}
\hline Pre-test & Post-test \\
\hline Skor total: 25 & Skor total: 16 \\
\hline
\end{tabular}




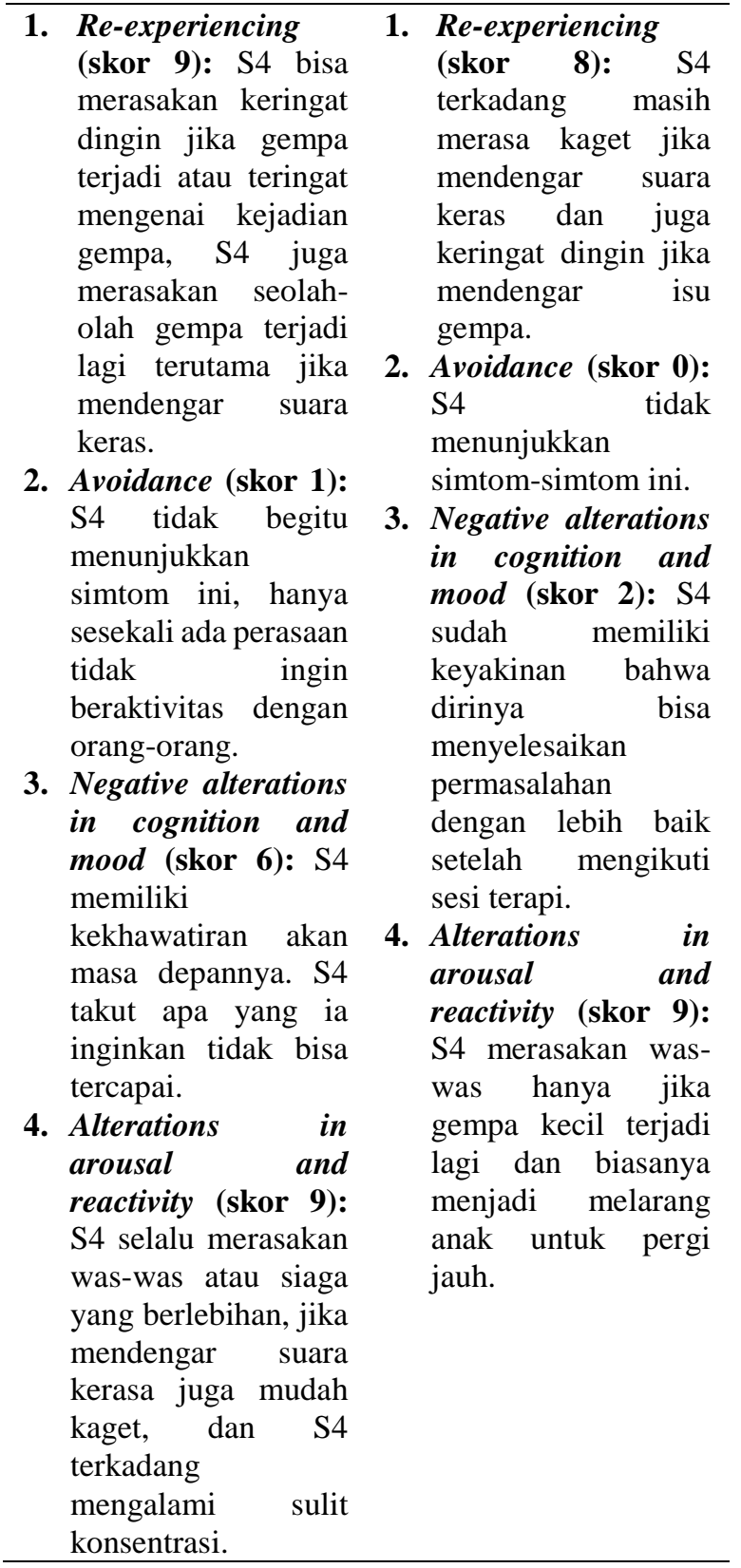

Pada S4 (Subjek 4), ia dapat menjalankan setiap tugas menggambar yang diberikan dengan baik. Jika dibandingkan dengan subjek lainnya, S4 merupakan subjek yang menggambar dengan cepat dan tidak banyak gambar yang dibuatnya. S4 dapat menceritakan berbagai hal yang ia rasakan dan pikirkan dengan sangat terbuka dan mendalam. S4 memiliki perasaanperasaan positif yang seimbang dengan perasaanperasaan negatif di dalam dirinya. Proses creative connection yang berlalu membawa S4 menemukan makna-makna hidup yang membuatnya menjadi yakin dan optimis dalam memandang masa depan. S4 juga merasa menjadi lebih mudah memahami dirinya dengan bercerita kepada orang lain. Pada proses yang dilalui oleh S4, karya yang dihasilkan berfungsi sangat baik dalam membantu S4 mengomunikasikan apa yang terdapat di dalam pikiran dan perasaannya. Meskipun gambar yang dihasilkan tidak begitu banyak dan hanya digambar dalam waktu singkat, S4 dapat mengekspresikan apa yang dirasakannya dan menceritakan hal-hal yang tidak terdapat pada gambar.

\section{KETERBATASAN PENELITIAN}

Dalam pelaksanaan seluruh rangkaian penelitian ini masih terdapat keterbatasan penelitian, yaitu terkait dengan waktu pelaksanaan intervensi yang terbatas. Penelitian ini dilakukan selama satu bulan dengan asumsi yang sama terhadap seluruh subjek penelitian bahwa dengan lima kali sesi terapi bisa mengurangi simtom-simtom PTSD yang dialami. Namun setelah berjalannya proses intervensi, dapat diketahui bahwa kondisi dan permasalahan yang dihadapi setiap orang berbeda-beda dan memungkinkan subjek penelitian membutuhkan waktu yang berbeda-beda dalam proses terapinya.

\section{SIMPULAN}

Kesimpulan dari penelitian ini adalah Pemberian intervensi Person-Centered Art Therapy efektif dalam menurunkan simtom PTSD pada subjek penelitian yang merupakan penyintas bencana gempa di Lombok dilihat dari adanya penurunan skor simtom PTSD pada keempat subjek. Efektivitas dari intervensi juga didukung oleh perubahan yang dirasakan masingmasing subjek. Proses creative connection yang digunakan dalam penyusunan tema di dalam setiap sesi intervensi serta sikap terapis yang menerapkan prinsipprinsip dalam Person-Centered Therapy membantu memfasilitasi subjek penelitian untuk bisa mengekspresikan diri dengan menyampaikan apa yang dirasakan dan dialami oleh masing-masing subjek secara terbuka dan memfasilitasi subjek untuk lebih mengenali dan memahami dirinya sendiri.

\section{DAFTAR PUSTAKA}

American Psychiatric Association. (2013). Diagnostic and Statistical Manual of Mental Disorders Fifth Edition DSM-5. Washington DC: American Psychiatric Publishing.

Badan Nasional Penanggulangan Bencana. (2018). Dampak Gempa Lombok: 436 Orang Meninggal dan Kerugian Ekonomi Lebih dari 5.04 Trilyun Rupiah. Retrieved from https://www.bnpb.go.id/berita/dampak-gempalombok-436-orang.

Creswell, J. W. (2009). Research Design: Qualitative, Quantitative, and Mixed Methods Apporaches. USA: Sage Publications.

Esparza, J. (2015). Using Person-Centered Expressive Arts Group Therapy with Combat-Related PTSD Veterans. Saybrook University. 
Everly, G. S. \& Lating, J. M. (2002). A Clinical Guide to the Treatment of the Human Stress Response (Second Edition). New York: Kluwer Academic/Plenum Publishers.

Feist, J., Feist, G. J. (2009). Theories of Personality Seventh Edition. New York: McGraw-Hill Companies, Inc.

Foa, E. B., Riggs, D. S., Dancu, C. V., \& Rothbaum, B. O. (1993). Reliability and validity of a brief instrument for assessing post-traumatic stress disorder. Journal of traumatic stress, 6(4), 459473.

Friedman, M. J., Keane, T. M., \& Resick, P. A. (2014). Handbook of PTSD Science and Practice (Second Edition). New York: Guilford Press.

Fullerton, C. S. \& Ursano, R. J. (2005). Psychological and Psychopatological Consequences of Disasters. England: John Wiley \& Sons.

Kirschenbaum, A. (2004). Chaos Organization and Disaster Management. USA: Marcel Dekker.

Malchiodi, C. A. (2007). The Art Therapy Sourcebook. USA: McGraw-Hill.

Neria, Y., Nandi, A., \& Galea, S. (2008). Posttraumatic stress disorder following disasters: a systematic review. Psychological medicine, 38(4), 467.

North, C. S., Oliver, J., \& Pandya, A. (2012). Examining a comprehensive model of disasterrelated posttraumatic stress disorder in systematically studied survivors of 10 disasters. American Journal of Public Health, 102(10), e40-e48.

Pamelia, E. M. (2015). Therapeutic Art-Making and Art Therapy: Similarities and Differences and a Resulting Framework. Indiana University.

Rogers, N. (1993). The Creative Connection: Expressive Arts as Healing. USA: Science \& Behavior Books, Inc.

Rubin, J, A. (2005). Artful Therapy. New Jersey: John Wiley \& Sons, Inc.

Rubin, J. A. (2010). Introduction to Art Therapy Sources \& Resources. USA: Routledge.

Stein, D. J., Friedman, M., \& Blanco, C. (2011). Posttraumatic stress disorder (Vol. 26). UK: John Wiley \& Sons.

Susanty, E. (2012). Efektivitas Terapi Eye Movement Desensitization and Reprocessing (EMDR) dalam Penanganan Post-traumatic Stress Disorder (PTSD) Pada Ibu Rumah Tangga Penyintas Bencana Gempa di Desa Pangalengan, Jawa Barat. Jatinangor: Fakultas Psikologi Universitas Padjadjaran.

Wilson, J. P., Friedman, M. J., \& Lindy, J. D. (2001). Treating Psychological Trauma PTSD. USA: The Guilford Press. 